University of Nebraska - Lincoln

DigitalCommons@University of Nebraska - Lincoln

To Improve the Academy

Professional and Organizational Development Network in Higher Education

1994

Knowledge Into Wisdom: Incorporating Values and Beliefs to

Construct a Wise University

Susan M. Awbrey

David K. Scott

Follow this and additional works at: https://digitalcommons.unl.edu/podimproveacad

Part of the Higher Education Administration Commons

Awbrey, Susan M. and Scott, David K., "Knowledge Into Wisdom: Incorporating Values and Beliefs to Construct a Wise University" (1994). To Improve the Academy. 301.

https://digitalcommons.unl.edu/podimproveacad/301

This Article is brought to you for free and open access by the Professional and Organizational Development Network in Higher Education at DigitalCommons@University of Nebraska - Lincoln. It has been accepted for inclusion in To Improve the Academy by an authorized administrator of DigitalCommons@University of Nebraska - Lincoln. 


\section{Knowledge Into Wisdom: Incorporating Values and Beliefs to Construct a Wise University}

\section{Susan M. Awbrey}

Oakland University

\section{David K. Scott}

University of Massachusetts at Amherst

Philosopher Nicholas Maxwell argues that universities today are founded on a philosophy of knowledge that is too narrowly focused on solving the technical problems of specialized academic disciplines. Maxwell believes that the foundation for the university should be a new type of inquiry that would have as its aim the improvement of not only knowledge but personal and global wisdom-a type of inquiry that would help us address the larger, complex problems that threaten our society. The authors agree with Maxwell but submit that the university has already begun a transformation to the philosophy of wisdom. As evidence of this organizational transition, current debates within the academy which relate to the components of wisdom are analyzed. A model for the development of wisdom is presented and its stages compared to the historical development of the university. The authors argue that universities should both exemplify and foster wisdom. Instructional implications of the philosophy of wisdom are explored. 
Since early Greek culture and before, wisdom has been prized. Plato's dialogues indicate a recognition that the concept of wisdom is multifaceted, referring to the "pursuit of truth" through contemplation (sophia), to "practical wisdom" (phronesis), and to a form of "scientific" or natural knowledge (episteme) (Robinson, 1990). Wisdom was based on the integration and harmony of these ideals. Our conception of wisdom is deeply embedded in our beliefs about how we come to know.

As we enter a new century, we are seeing a revival of interest in the study of wisdom and the more balanced world view it represents. This resurgence is due in part to the search for a vision that will restore harmony and inspire us to meet the challenges of our time. Society is engaged in unprecedented upheaval and change. The values of individualism and competitiveness upon which America was founded appear not only to be inadequate but in many ways antithetical to the teamwork and interdependence called for in a new global age.

The workforce of tomorrow will require the ability to construct meanings from knowledge (abstraction), the ability to recognize connections and interrelationships (systems thinking), the ability to reach beyond what is known (experimentation), and the ability to successfully work with others to achieve mutual goals (collaboration) (Reich, 1991). These are not skills that can be acquired through spectator methods of education nor can they be apprehended through an education focused on the accumulation of facts alone. Many voices, not only from outside but from within our universities, are calling for a change in our educational institutions (Atkinson, 1992; Bok, 1990; Rhodes, 1993.) There is a growing recognition that universities, like institutions of government and industry, are undergoing a fundamental transformation. To be successful, this transformation must reach to the very heart of the university and unveil the values and beliefs which form its foundation (Scott \& Awbrey, 1993).

Throughout history, society has expected universities to contribute to the development of effective citizens and to the solution of societal problems. By the late Middle Ages, there were "pressures to harness education to professional, ecclesiastical, and governmental needs" (Klein, 1990). This pressure led to the rise of disciplines. It is interesting to note that it was external pressure which first led to the 
profound specialization we experience today. Ironically, it is this very specialization that has created a gulf between the university and its ability to respond to the problems and issues society currently faces. Philosopher Nicholas Maxwell notes that universities today are founded on a philosophy of knowledge-they are focused too narrowly on the limited, technical problems of specialized academic disciplines. He states that we need "a new kind of inquiry [that] would have as its basic aim to improve, not just knowledge, but rather personal and global wisdom" (Maxwell, 1992, p.205).

The "official basic creed" of the academic enterprise is that "rational inquiry ought to help enhance the quality of human life by, first, improving knowledge." However, Maxwell reminds us that "intellectual priority needs to be given to the dual tasks of articulating our problems of living, and proposing and criticizing possible solutions ... Problems of knowledge and understanding need to be tackled as rationally subordinate to intellectually more fundamental problems of living" (Maxwell, 1984, p.3). Essentially, Maxwell is saying that universities must move from a limiting philosophy of knowledge to a philosophy of wisdom. We believe that this broader vision must be found if we are to inhabit a world in which people are prepared and willing to deliberate about issues that affect their lives and to take responsibility for decisions that will maintain and enhance democracy.

In considering how a change to the philosophy of wisdom might impact our universities, it is first necessary to say what one means by wisdom. Many definitions from ancient to modern times have been offered. We cannot do justice here to this historical perspective. However, most concepts of wisdom view it as the end point of a process that encompasses the idea of making sound judgments in the face of uncertainty. It is how we address the deep, unstructured questions that life presents us. "The essence of wisdom . . . lies not in what is known but rather in the manner in which that knowledge is held and in how that knowledge is put to use" (Meacham, 1990). Wisdom then requires not only a knowledge base (factual and experiential), but an awareness of the contextual nature of knowledge (awareness that one's own views and those of others are interpretations), and awareness that knowledge is a temporary settlement based 
on the current best evidence (recognition of uncertainty) (Kitchener \& Brenner, 1990).

Karen Strohm Kitchener and P.M. King have developed a model for the development of reflective judgment. Its stages include:

1. Knowledge simply exists and, therefore, does not need justification. Knowledge is concrete.

2. Knowledge is absolutely certain, or certain but not immediately available. We can know directly or via authorities.

3. Knowledge is absolutely certain or temporarily uncertain. In the areas of temporary uncertainty, we can know only via our intuitions or biases.

4. Knowledge is idiosyncratic since situational variables dictate that we cannot know with certainty.

5. Knowledge is contextual and subjective. Since what is known is known via perceptual filters, we cannot know directly. We may know only interpretations of the material world.

6. Knowledge is personally constructed via evaluations of evidence, opinions of others, etc., across contexts; thus we may know our own and other's personal constructions of issues.

7. Knowledge is constructed via the process of reasonable inquiry into generalizable conjectures about the problem at hand, e.g., which interpretation seems most probable based on the current evidence. (Adapted from Kitchener \& Brenner, 1990, p.218)

In these last stages we see the emergence of wisdom when there is awareness that knowledge

must be constructed via critical inquiry or through the synthesis of opposing views. Such constructions often go beyond the evaluations of others' perspectives. Rather, they are generative, offering, much like [the biblical] Solomon, a new, more complete way to view the issue under consideration. (Kitchener \& Brenner, 1990)

Although wisdom is often associated with old age (Clayton \& Birren, 1980; Erickson, 1982), empirical evidence is not adequate to draw such a conclusion, and older people appear less likely to endorse this age relationship than the young or middle-aged (Meacham, 1990). Still, even if the final stages of wisdom emerge at an age beyond that of many college students, we believe that it is the responsibility of 
educational institutions to assist students to move through the stages of development toward wisdom. In addition to providing the student with a foundation, the university should also provide a model for wisdom in the environment it creates. Universities should not just foster wisdom but should exemplify it.

Too often we view institutions as monoliths of bricks and mortar on which we can have little impact. Yet, organizations are made up of people. Their policies, procedures, administrations, operations are all determined by the people who inhabit them. They are, as Bellah, et al. (1991) note, patterned ways that people live together. Universities are institutions of people-people responding to their times. Because of this, we would like to use wisdom as a metaphor for how universities have developed to reflect the people who inhabit them and how some of the current issues within the university can be viewed from this perspective. We believe that the university itself has been struggling through the stages of development toward wisdom and that debates about aspects of wisdom have been occurring on many fronts - often without their participants identifying them as such. In short, we believe the transition from a philosophy of knowledge to a philosophy of wisdom has begun, however marginally, in higher education.

\section{Which Knowledge-Base?}

One very fundamental debate within the university has been the debate over canon. As we have seen, researchers identify a factual and experiential knowledge base as an important element of wisdom although not a sufficient condition for it (Meacham, 1990; Kitchener \& Brenner, 1990). There has been a long-standing debate within the academy over what should form the fundamental knowledge base of the university.

There are those like Robert Maynard Hutchins who contend that "Education implies teaching. Teaching implies knowledge. Knowledge is truth. The truth is everywhere the same. Hence education should be everywhere the same" (Oakley, 1992, p.125). This theme seems to have been taken up by many conservative critics for whom pluralism and multiculturalism have become the rocks upon which Western Civilization has foundered. It has, they believe, created a 
"cultural relativism" that began in the 1960s (Bloom, 1987). However, Francis Oakley's (1992) work helps us to recognize that the "roots of the women's movement are deeply engaged in nineteenth-century soil"; that programs of study of what later became called the "Third World" began in the 1950s; that the establishment of African-American studies was generated by the change in race relations that began after the Second World War; and that 'the seeds of doubt about [Western civilization core-curriculum's] viability had begun to germinate even before the 1950s" (Oakley, 1992, p.131). Thus, the rise of pluralism cannot be dismissed as simply an invention of radicals during the 1960s. If we examine Kitchener and King's model of wisdom, we also find that relativism is an important stage in the development of wisdom. It moves us from an authority based model of knowledge to one that recognizes the contextual nature of our knowing.

As Benjamin Barber notes:

There has been no single historical canon, but an evolving argument. And if the canon turns us into "Us", we in turn transform the canon into "The Canon": It creates Us as we create It. As we are heterogeneous, our story in time necessarily becomes plural, plural in that each generation rewrites it, plural in that it must confront the reality of pluralism in the makeup of the nation. The more inclusive the story, the more pluralistic its plot. (Barber, 1992, p.27)

The authors believe that to form a wise university it is important to maintain an historical perspective, a knowledge base if you will. We, like Tarnas (1991), affirm the importance of history and recognize the project of Western Civilization as "a necessary and noble part of a great dialectic" which has prepared the way for a "larger synthesis". But we contend that the university's knowledge base must expand these boundaries. It must be not only inclusive but recognized as representing differing perspectives on the same events.

\section{Living with Uncertainty}

A second debate within the university centers on the tension between theory and practice. During the early stages of university history, the search for knowledge focused on the search for fixed, 
antecedent invariants often attributed to the divine. Action and practical activity were eschewed as fraught with potential failure and frustration. The deep desire for certainty and freedom from risk is a natural human characteristic as "man who lives in a world of hazards is compelled to seek for security" (Dewey 1929/1988, p.3). Unfortunately, according to John Dewey, this desire led to three mistakes in ancient thought:

the first, that certainty, security, can be found only in the fixed and unchanging; the second, that knowledge is the only road to that which is intrinsically stable and certain; the third, that practical activity is an inferior sort of thing, necessary simply because of man's animal nature and the necessity for winning subsistence from the environment. (Dewey 1929/1988, p.41)

With the rise of the scientific method, this search for invariants gave way to the search for constant relations among changes (Dewey 1929/1988). Experiment replaced belief. This new acceptance of action was a primary step toward the development of a philosophy of wisdom, and society looked optimistically to science for bright, new solutions to its ills. However, recently, this optimism has waned. Is this because the idea of active inquiry is flawed? We submit that it is not inquiry that is flawed but only our narrow conception of it. The academy, through its specialization and reward structure, has limited inquiry to narrow forms of technical rationality (Schön, 1994). As Derek Bok points out, the problems that attract outstanding scholars are those susceptible to verifiable experiments while the large, neglected societal problems appear value-laden and seemingly intractable (Bok, 1990, p.45). Lee Shulman (1994) comments that those parts of the university that most directly address the agenda for the improvement of life and living - schools of social work, nursing, educationare the most fragile, marginal, gendered, and vulnerable to closing or merger in times of budget crisis. Further, he notes that the investigators who are most successful in these schools are often those who embrace research paradigms that "flee the furthest" from the social amelioration and social change for which the schools were created. He calls this the process of "deconstruction to the closest relevant discipline"a process in which research in these professional schools is couched 
in the jargon of disciplines that are seen as more prestigious and scientific.

Donald Schön (1994) and others have suggested that new methods of inquiry must be identified to address the types of unstructured, real-life problems that are the center of Nicholas Maxwell's argument. Indeed, rather than being anti-action, these methods must be steeped in practice. According to Schön, most "civilizing problems" are of the type in which it is impossible to discriminate among hypotheses about what is going on. In order to deal with such problems, Schön suggests that we must become "reflective designers" under conditions of uncertainty. Because we are unable to set out variables, we must reflect on the situation's "pattern causality." Pattern causality is the combination of design causality, in which things happen because you intend them to and act to bring about results, and efficient causality, in which your actions produce unintended consequences. Under conditions of pattern causality, we must look for causes by tracing back events in time and space and then doing on the spot checks and experiments to confirm our hunches. This, says Schön, is the difference between social inquiry and social science. New kinds of inquiry, measurement, and documentation similar to those Schön describes elsewhere have been referred to as action science (Argyris, Putnam, and Smith 1985) and design experiments (Shulman, 1994).

If the university is to embrace the philosophy of wisdom, it must give place to these broader interpretations of inquiry. Indeed, this process has already begun. Throughout the academy - in mathematics, economics, anthropology, education, natural sciences - an unrest with the adequacy of current methods for studying complex systems is emerging. As Shulman notes, this movement is still marginal, and those within it remain in a vulnerable, fragile condition within the university. Yet, an awareness of the importance of this transition is beginning to appear across the academy. Proponents do not advocate the replacement of standard quantitative methods but an expansion of options for handling systems not well described within a quantitative framework. 


\section{The Contextual Nature of Knowing}

Through the centuries in Western civilization a dualistic view of human cognition has arisen. It has separated meaning apprehended through logical, deductive modes from those acquired through intuitive and aesthetic approaches (Labouvie-Vief, 1990). The rise of the scientific method produced the age of modernism characterized by the positivist, empiricist, rational-logical model of modern science and inspired by individuals such as Russell, Carnap, Wittgenstein, and Husserl (Neville, 1992, pp. 5-11). The scientific method was developed with good reason, and it moved our inquiries beyond mere appeals to authority. However, as we have seen, the strict, narrow interpretation of empiricism by the positivists eventually led to disillusionment (Rousneau, 1992, p.10).

This disillusion with modernism's ability to lead us to a "good world" gave rise to the post-modern movement, inspired by Nietzsche and Heidegger. Post-modernism is a complex term covering many different views. However, post-modernism "rejects epistemological claims, refutes methodological conventions, [and] resists knowledge claims" (Rousneau, 1992, p.3). Post-modernism is a radical response to modernism's narrow viewpoint. It attempts to shake our complacency while creating an awareness of the role of interpretation in cognition. We noted earlier that a third element of wisdom as described by Kitchener \& Brenner (1990) is the recognition that our knowledge depends upon the interpretations we and others make. Perhaps no issue has obtained such prominent deliberation in this post-modern era as the debate over interpretation.

But must we conclude that empiricism with its great achievements is incompatible with interpretation, or can we broaden our view of inquiry to include both logical and intuitive forms of knowing? We believe this is not only possible but has long been a part of the scientific method although not recognized by the narrow positivist view of science that the post-modernists criticize. For example, in physics, Chandrasekhar (1987, p. 65) cites renowned scientist Hermann Weyl as saying, "My work always tried to unite the true with the beautiful; but when I had to choose one or the other, I usually chose the beautiful." Weyl made this statement in reference to his gauge theory 
of gravitation because he was convinced that this theory was not true as a theory of gravitation, but it was too beautiful for him to abandon. Chandrasekhar (1987, p. 66) notes that "much later, it did turn out that Weyl's instinct was right after all, when the formalism of gauge invariance was incorporated into quantum electrodynamics." Erwin Schrödinger is also reputed to have said that it is more important to have beauty in your equations than to have them fit experiments. Nobel prize-winning geneticist Barbara McClintock indicates that what enabled her to reach deeper and further into the mysteries of genetics than her colleagues was an "openness to let it come to you", the ability to "hear what the material has to say to you," and "a feeling for the organism" (Keller, 1983, p.197). We mention these examples from intellectual giants of the twentieth century because they illustrate clearly that great scientists have always included factors other than empiricism in arriving at the truth. The question becomes not if, but how widely, we are to draw the circle of inclusion of non-empirical factors in the development and the testing of scientific theories. As we have seen, Nicholas Maxwell proposes that the envelope be pushed much further. By so doing, he believes we will accelerate our progress to truth and to a better and wiser world.

Maxwell can find support for this thesis in the emerging field of cognitive science. Nersessian and others who study how scientists think have developed a process of cognitive-historical analysis. The main premise of this practice is that "the problem-solving strategies scientists have invented and the representational practices they have developed over the course of the history of science are very sophisticated and refined outgrowths of ordinary reasoning and representational processes" (Nersessian, 1992, p.5). Nersessian, through the study of the thought patterns of scientists such as James Clerk Maxwell and Michael Faraday, has shown that throughout history there is recurrent use of analogical reasoning, imagistic reasoning, thought experiment, and limiting case analysis, elements that clearly go beyond the positivist view of empiricism. She states that "the problem becomes that of how it is that scientists, working individually or collectiveiy, combine the cognitive abilities they have in virtue of their biology with the conceptual resources they acquire from the 
various facets of their lives in a wider community" (Nersessian, 1992, p.38).

But an examination of the history of philosophy shows us that there have been ways around the narrow definition of empiricism developed by the modernists all along:

Of particular importance is the development within the Peircean lineage of a concern for value in experience. Moving down from Peirce are two tightly interwoven lines of descent. The first is the pragmatic tradition of James, Dewey, Mead, and others. The second is the adoptive lineage of Whitehead's process philosophy...Like Peirce just before him, Whitehead went around modernism. (Neville 1992, p.18)

\section{The Development of a Wise Institution}

From this limited discussion of issues being debated within the academy, we begin to see how members of our universities, over time, have moved our institutions through stages analogous to those of Kitchener and King's model of wisdom. We recognize the first three stages of the model as representing a belief in the certainty of knowledge based in authority. This can be seen as the foundation of early universities and monastic guilds during an age of divine wisdom. Stage four of the model represents the period during which the certainty of this divine plan came into question after the Copernican revolution. Stage five and the beginning of stage six represent our current post-modern debate in which logical, deductive vs. aesthetic and narrative forms of knowing are in tension. Stages five and six can also be seen as representing the current fragmentation of our multiversities in which knowledge is viewed from the perspective of each discipline, and judgment about which perspective is best is often based on ethnocentric, disciplinary criteria. To construct a university based on the philosophy of wisdom will require us to move to stage seven of Kitchener and King's model. Stage seven represents a resolution of opposing views not through selection but through synthesis. It is generative in that new, more complete perspectives emerge from a synthesis of the old. This stage calls for new forms of connection and inclusion not only across disciplinary boundaries within the university but across the boundaries that separate the university from society. We have argued that this transformation is already in progress and will be 
vital to creating an institution that is relevant and effective in the twenty-first century.

\section{What This Implies for Teaching and Learning}

Even if we succeed in constructing a university environment that exemplifies the philosophy of wisdom, this model will be insufficient to nurture wisdom in our students unless it extends to their instruction. William Perry's (1968) studies identified stages of growth in a college student's world view. According to Perry, the student first takes a dualistic "we-right-good vs. other-wrong-bad" view. Second, the student accounts for diversity of opinion and uncertainty by seeing them as a product of a poorly qualified authority who hasn't found the answer. Next, he/she takes a relativistic point of view in which everyone is entitled to his/her own opinions. In later stages the student identifies the contextual nature of knowing and sees the need to orient him/herself through personal commitment, accepting the responsibility that such commitment entails. If we believe that the achievement of the later stages of development represented by Perry and the Kitchener and King model are the ultimate goal of education based on a philosophy of wisdom, this has several implications for the educational enterprise.

The ability to recognize that our knowledge is only the temporary settlement of questions based on the best current evidence is perhaps one of the most important lessons from wisdom that can inform our instruction. By allowing teachers to act as catalysts of learning rather than authority figures, we can help students to understand and appreciate the uncertain character of our knowledge. The use of active inquiry and critical thinking will allow them to move through the stages of puzzlement, action, and reflection that John Dewey, long ago, recognized as crucial elements of learning. Engagement of students in active learning is essential if we wish them to develop the habits of reflective judgment. Spectator methods of instruction in which students sit passively listening to authoritarian role models will do little to assist this process. Fortunately, advancements in learning technology have opened new avenues for learning which, if used 
effectively, can assist in providing students with environments that actively involve them as participants in their learning.

But Nicholas Maxwell has challenged us to take the idea of uncertainty one step further. We have seen how the scientific method has replaced the method of authority and the certainty of fixed invariant knowledge. Yet, within the academy we have also seen that our explorations are most often constrained to those areas in which outcomes are, if not certain, at least quite predictable. Maxwell has challenged us to once again tolerate ambiguity and uncertainty by addressing the complex, unstructured questions that face and threaten our society - to reach beyond the surety of our certain methods and to explore new ways of knowing and assessing. If we are to take this call seriously and to create an institution that embraces a philosophy of wisdom, we must act to develop new methodologies for inquiry and encourage our students to join in the exploration of these great questions.

An awareness that the knowledge we hold is an interpretation of our perceptions was also identified in our earlier discussion as a key element of wisdom. Often knowledge is presented to students with little discussion of the assumptions that underlie it. An increase in deliberation among students and within and between instructors and departments is needed to reveal the contextual nature of knowing. The abilities to identify our underlying assumptions and to recognize that our ideas are not context-free are major components of critical thinking. "When we are aware of how hidden and uncritically assimilated assumptions are important to shaping our habitual perceptions, understandings, and interpretations of the world, and to influencing the behaviors that result from these interpretations, we become aware of how context influences thought and actions" (Brookfield, 1987, p.8). To be effective in fostering critical thinkers who are contextually aware, it is important that instructors question the assumptions that underlie the knowledge, values, and methods used in their instruction and that they invite students to question their own assumptions as well as those of the instructor. This is a task that requires courage and openness.

Unexamined assumptions can lead to insular views. We noted earlier that our universities have become profoundly specialized and 
departmentalized. This departmentalization has led to boundaries that have lost their permeability between disciplines. Communications across these boundaries have become limited. Varying interpretations have made it difficult, and in some cases almost impossible, to form the types of collaboration necessary to explore questions that demand creativity and require contributions from a wide and diverse team. Schön (1994) noted that to increase cooperative inquiry we must model it in what we say and do. Beyond modeling collaboration, we must also give students practice in working in collaborative teams. Yet, much of our educational system is still founded on ideas of competitiveness.

Implications can also be drawn for how we teach the knowledge base that underlies wisdom. Studies of problem-solving by medical students during clinical diagnosis reveal that the way in which information is learned and stored can have a profound effect on how it will later be used. Traditional methods of teaching basic science courses interfere with the ability to access and use that information during problem-solving and diagnosis. The problem-solving and decisionmaking of medical students has been studied intensely. Less attention has been paid to the real world problem-solving of students in other fields. Still, it seems likely that the difficulties experienced by medical students in accessing and using their knowledge is not an exception.

If, as Secretary of Labor Robert Reich suggests, problem-solving is a primary skill that will be necessary for success in tomorrow's work force and, as Nicholas Maxwell and others suggest, problem-solving is essential for the well-being of individuals and the world they inhabit, then attention needs to be paid not only to what information we believe students must acquire as a knowledge base but to making sure that this knowledge is continually linked to the types of problem-solving that it is intended to undergird. One way of insuring such transfer is to involve students in consistent realistic practice and problem-solving throughout their educational experience. A system of education built on the philosophy of wisdom would require a reexamination of the place of practice and application in student education.

Although many changes are underway in postsecondary education, to fully embrace and exemplify a philosophy of wisdom will require the creativity and dedication of the entire university commu- 
nity. It is a significant challenge, but one we believe it will be essential to meet if higher education is to move successfully into the next century.

\section{References}

Argyris, C., Putman, R., \& Smith, D.M. (1985). Action science concepts, methods, and skills for research and intervention. San Francisco: Jossey-Bass.

Atkinson, R.C. \& Tuzin, D. (1992, May/June). Equilibrium in the research university. Change, 24 p. 20.

Barber, B.R. (1992). An aristocracy of everyone: The politics of education and the future of America. New York: Ballantine Books.

Bellah, R.N., Madsen, R., Sullivan, W.M., Swidler, A., \& Tipton, S.M. (1991). The good society. New York: Vintage Books.

Bloom, A. (1987). The closing of the American mind. New York: Simon and Schuster.

Bok, D. (1990). Universities and the future of America. Durham: Duke University Press.

Brookfield, S.D. (1987). Developing critical thinkers. San Francisco: Jossey-Bass.

Chandrasekhar, S. (1987). Truth and beauty. Chicago: The University of Chicago Press.

Clayton, V. \& Birren, J.E. (1980). The development of wisdom across the life span: A reexamination of an ancient topic. In P.B. Baltes and O.R.Brim(Eds.), Life span development and behavior (pp. 103-135). New York: Academic Press.

Dewey, J.([1929], 1988). The quest for certainty: A study of the relation of knowledge and action. In J.A. Boydston (Ed.). John Dewey: The Later Works, 1925-1953, Vol 4: 1929 (pp. 1-254). Carbondale, IL: Southern Illinois University Press.

Erikson, E.H. (1982). The life cycle completed. New York: Norton.

Keller, E.F. (1983). A feeling for the organism. San Francisco: W.H. Freeman.

Kitchener, K.S., \& Brenner, H. G. (1990). Wisdom and reflective judgment: Knowing in the face of uncertainty. In R.J. Sternberg (Ed.). Wisdom: Its nature, origins, and development (pp. 212-229). Cambridge, U.K.: Cambridge University Press.

Klein, J.T. (1990). Interdisciplinarity: History, theory, \& practice. Detroit: Wayne State University Press.

Labouvie-Vief, G. (1990). Wisdom as integrated thought: Historical and developmental perspectives. In R.J. Sternberg (Ed.), Wisdom: Its nature, origins, and development (pp. 52-83). Cambridge U.K.: Cambridge University Press.

Maxwell, N. (1984). From knowledge to wisdom: A revolution in the aims and methods of science. London: Basil Blackwell.

Maxwell, N. (1992). What kind of inquiry can best help us create a good world? Science, Technology, \& Human Values. 17(2), 205-227.

Meacham, J.A. (1990). The loss of wisdom. In R.J. Sternberg (Ed.), Wisdom: Its nature, origins, and development (pp. 181-211). Cambridge, U.K.: Cambridge University Press. 
Nersessian, N.J. (1992). How do scientists think? In R.N. Giere (Ed.) Cognitive models of science. (pp. 3-43) Minneapolis: University of Minnesota Press.

Neville, R.C. (1992). The highroad around modernism. Albany, NY: State University of New York Press.

Oakley, F. (1992). Community of learning: The American college and the liberal arts tradition. New York: Oxford University Press.

Pascual-Leone, J. (1990). An essay on wisdom: Toward organismic processes that make it possible. In R.J. Sternberg (Ed.), Wisdom: Its nature, origins, and development (pp. 244-278). Cambridge, U.K.: Cambridge University Press.

Perry, W.G. (1968). Forms of intellectual and ethical development in the college years: A scheme. New York: Holt, Rinehart \& Winston.

Reich, R.B. (1991). The work of nations. New York: Vintage Books

Rhodes, F. (1993). Institutions under stress: American universities at the fin de siecle. In Proceedings of Bridging the Atlantic: Sharing Ideas And Ideals. Fourth Annual International AAUA Conference in Dublin, Ireland (pp. 66-80). University Park, IL: American Association of University Administrators.

Robinson, D.N. (1990). Wisdom through the ages. In Robert J. Sternberg (Ed.). Wisdom: Its nature, origins, and development (pp. 13-24). Cambridge, U.K.: Cambridge University Press.

Rosenau, P.M. (1992). Post-modernism and the social sciences. Princeton, NJ: Princeton University Press.

Schön, D. (Speaker). (1994). Response to What kind of inquiry can best help us create a good world? (Cassette Recording No. 94CFFR-34). Washington, D.C.: American Association for Higher Education.

Shulman, L. (Speaker). (1994). Response to What kind of inquiry can best help us create a good world? (Cassette Recording No. 94CFFR-34). Washington, D.C.: American Association for Higher Education.

Scott, D.K. \& Awbrey, S.M. (1993). Transforming the university. In Proceedings of the Conference on Women in Science and Engineering, Bloomington, IN: Committee on Institutional Cooperation.

Tarnas. R. (1991). The passion of the western mind. New York: Ballantine Books. 